\title{
改良二流体モデルによる原子炉熱設計手法の開発* （中口径管に対する乱流拡散カモデルの適用性評価）
}

\author{
細井 秀章*1，吉田 啓之*2

\section{Development of Numerical Procedure for Thermal Hydraulic Design of Nuclear Reactors with Advanced Two-Fluid Model \\ (Applicability of Turbulent Dispersion Force Model for Middle Diameter Vertical Pipe)} \\ Hideaki HOSOI ${ }^{* 1}$ and Hiroyuki YOSHIDA \\ ${ }^{* 1}$ Univ. of Tsukuba. Graduate School of Systems and Information Engineering Master's Program \\ 1-1-1, Tennoudai, Tsukuba, Ibaraki, 305-8573, Japan \\ An advanced two-fluid model has been developed in Japan Atomic Energy Agency (JAEA). In this model, an \\ interface tracking method is combined with a two-fluid model. In this procedure, liquid clusters and bubbles larger than \\ a computational cell are calculated using the interface tracking method, and those smaller than a cell are simulated by \\ the two-fluid model. A turbulent dispersion force term is one of the most important constitutive equations for advanced \\ two-fluid model. We have developed the new model for turbulent dispersion force and verified the developed model \\ using the 3-dimensional two-fluid model code ACE-3D, and the comparisons between the results of the analyses and \\ air-water two-phase flow experiments in $200 \mathrm{~mm}$ diameter pipe. In this study, to verify the applicability of developed \\ model for middle diameter vertical pipe, we compared between the analyses of results and air-water two-phase flow \\ experiments in $38 \mathrm{~mm}$ diameter pipe.
}

Key Words : Advanced Two-Fluid Model, Constitutive Equations, Turbulent Dispersion Force, ACE-3D

\section{1. 緒言}

原子炬システムに対し，大型実験に依存しない熱設計手法を確立するため，日本原子力研究開発機構（以下， 原子力機構）では，熱流動解析を中心とした熱設計手法を開発している．原子炉システムでは，一般に蒸気と水 が混合した（気液）二相流が現れるため，ここで用いる熱流動解析でも二相流を取扱う必要がある。一般に，原 子カシステムの熱設計では，気液界面の影響を実験結果に基づく経験式（(二相流）構成式）で表現し，これによ り計算負荷を低減させた熱流動解析手法が用いられている。しかし，ここでは大型実験への依存性を排除するた め, 流路形状などの体系や流動条件への解析手法の依存性が小さい事が求められる. 実験結果に基づく構成式は, 本質的に体系や流動条件に強く依存する，従って，構成式を用いずに計算負荷が小さいという，熱設計で用いら れている手法とは異なる手法の開発が必要とされている。このような条件を満足する解析手法として，原子力機 構では，体系や流動条件で解析結果が大きく変化する液膜などの大きな界面構造に対しては，構成式を用いるこ となく評価が可能な界面追跡法を用い，計算負荷を大きくする要因となる小気泡や液滴などの小さな界面構造に 対しては，構成式を利用した二流体モデルで評価する，改良二流体モデルを開発している(1).これまでに，原子 力機構で開発した三次元二流体モデル解析コード ACE-3D に改良二流体モデルを組込み, 試計算等を行った ${ }^{(2)}$. その結果，手法の妥当性については確認されたものの，既存の二流体モデルに対して最適化された構成式の一部 の適合性に課題があると評価された。本研究では，改良二流体モデルに適合した構成式開発の一環として，乱流

\footnotetext{
* 原稿受付 2010 年 9 月 16 日

*1 学生員, 筑波大学大学院システム情報工学研究科（テ305-8573 茨城県つくば市天王台 1-1-1）

*2 正員, (独)日本原子力研究開発機構原子力基礎工学部門

E-mail: hhosoi@edu.esys.tsukuba.ac.jp
} 
拡散力に対する新たなモデルの提案を行っている，これまでに，改良二流体モデルに適合するとともに物理現象 に基づいたモデルを提案し, 管径 $200 \mathrm{~mm}$ の大口径管を用いた実験を模擬した解析を行い, 妥当性を検討した ${ }^{(3)}$. 本報では，モデルの妥当性評価の一環として，管径 $38 \mathrm{~mm}$ の中口径管を用いた実験を模擬した解析を行った.

\section{2. 改良二流体モデル}

\section{$2 \cdot 1$ 改良二流体モデルの概要}

図 1 に改良二流体モデルの概要を示す．本モデルでは，計算領域内にボイド率の異なる二つの領域を想定する (図 1 (a) 参照)。一つは, ボイド率が 0.5 未満の領域（気泡流領域と呼ぶ）であり，内部に小気泡のみを含むと 仮定する．もう一つは，ボイド率が 0.5 より大きい領域（噴霧流領域と呼ぶ）であり，内部に液滴のみを含むと 仮定する. 本手法では, これらの二つの領域間の, ボイド率が 0.5 の位置に大規模な界面が存在すると考え, 通 常の VOF 法における液相体積割合の代わりに，気泡流領域体積割合を用いることで，大規模な界面の追跡を可 能とする. また, 気泡流領域内の小気泡及び噴霧流領域内の液滴は二流体モデルで評価される (図 1 (b) 参照).

\section{$2 \cdot 2$ 改良二流体モデルの基礎式と構成式}

改良二流体モデルの基礎式は, 基本的に通常の二流体モデルと同様であり, 断熱非加熱条件に対して, 連続の 式及び運動量保存式が以下のように与えられる.

$$
\begin{gathered}
\frac{\partial}{\partial t}\left(\alpha_{k} \bar{\rho}_{k}\right)+\nabla \cdot\left(\alpha_{k} \bar{\rho}_{k} \overline{\boldsymbol{u}}_{k}\right)=0 \\
\alpha_{k} \bar{\rho}_{k}\left(\frac{\partial \overline{\boldsymbol{u}}_{k}}{\partial t}+\overline{\boldsymbol{u}}_{k} \cdot \nabla \overline{\boldsymbol{u}}_{k}\right)=-\alpha_{k} \nabla P_{k}+\nabla \cdot\left[\alpha_{k}\left(\overline{\boldsymbol{\tau}}_{k}+\overline{\boldsymbol{\tau}}_{k}^{\mathrm{Re}}\right)\right]+\alpha_{k} \bar{\rho}_{k} \boldsymbol{g}+\left(P_{k i}-P_{k}\right) \nabla \alpha_{k}+\boldsymbol{M}_{k}
\end{gathered}
$$

ここで， $t$ は時間， $\alpha$ は体積率， $\rho$ は密度， $\boldsymbol{u}$ は速度， $P$ は圧力， $\boldsymbol{\tau}$ は粘性応力テンソル， $\boldsymbol{\tau}^{\mathrm{Re}}$ はレイノルズ応力 テンソル, $\boldsymbol{g}$ は重力加速度, $\boldsymbol{M}$ は界面運動輸送量であり, 下付き添字の $k$ は $g$ （気相）または $l$ (液相), $i$ は気 液界面, オーバーバーは平均量を表す。上式において, 密度などの物性值は蒸気表などにより与えられる. 圧力 には, 一圧力モデル $P=P_{k}=P_{k i}$ を用いる. レイノルズ応力は, 標準 $k-\varepsilon$ モデルを二相流に拡張して評価する( ${ }^{(6)}$.

界面運動輸送量 $\boldsymbol{M}$ は, 改良二流体モデルでは以下のような構成式群で与えられる.

$$
\boldsymbol{M}_{k}=\boldsymbol{M}_{D}+\boldsymbol{M}_{V M}+\boldsymbol{M}_{L i f t}+\boldsymbol{M}_{T D}
$$

ここで, $\boldsymbol{M}_{D}$ は界面せん断力, $\boldsymbol{M}_{V M}$ は仮想質量力, $\boldsymbol{M}_{L i f t}$ は揚力, $\boldsymbol{M}_{T D}$ は乱流拡散力を表現する構成式を表す. 上述 の様に, 改良二流体モデルでは，小気泡及び液滴のみが構成式で取り扱われる. 従って, 気泡・液滴径が小

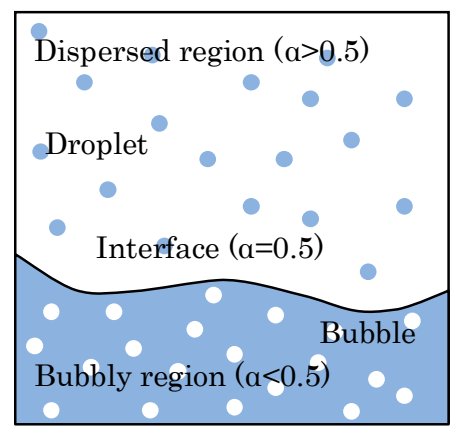

(a) Three numerical regions

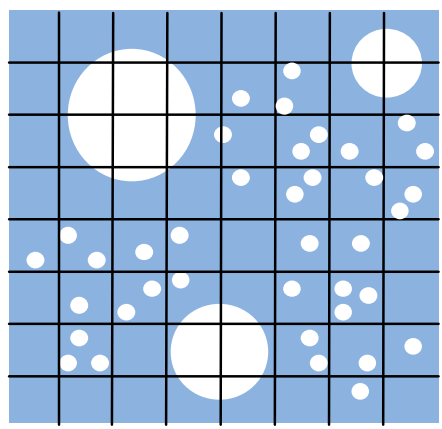

(b) Treatment of regions on numerical cells

Fig. 1 Schematic diagram of advanced two-fluid model 
さい事から，これらの構成式では球形気泡及び液滴のみを取り扱うことと仮定する． $\boldsymbol{M}_{D}, \boldsymbol{M}_{V M}$ 及び $\boldsymbol{M}_{L i f t}$ は球形 の気泡に対しては, 十分に物理的考察に基づく, 改良二流体モデルに適合したモデル化が行われていると判断し, 既存のモデルを用いる．既存の乱流拡散力に対寸る構成式は大気泡の影響を暗に含むとともに，改良二流体モデ ルに適合せず不安定化の要因と判断されたためモデル化の対象とした.

\section{3. 乱流拡散力に対するモデル開発}

本研究では, 乱流拡散現象と分子運動論 (Brown 運動 $\left.{ }^{(4)}\right)$ との類似性に基づき, 乱流拡散力のモデル化を行う. 図 2 に Brown 運動と本研究で考える乱流拡散現象の概要を示す. Brown 運動は流体中に浮遊する粒子が，流体分 子の衝突による駆動力を受けて摇動する現象である (図 2 (a) 参照). 粒子数密度分布に偏りが存在する場合に は, 粒子数密度の勾配に比例し, 確率的に分布が平坦化するように粒子が移動する.すなわち Brown 運動におけ る拡散力は，粒子に与えられる駆動力（運動量交換の程度）と粒子数密度の勾配に比例する.

図 2 (b)，（c）に示すように，乱流渦を流体塊の集合とみなすと，気泡の乱流拡散は，流体塊が衝突すること で与える駆動力により気泡が摇動し, 確率的に気泡数密度分布が平坦化する現象であると考えられる. そこで, まず，流体塊が与える駆動力について考える. Brown 運動のモデル化では，分子の持つ運動量の全てが粒子に与 えられると考える. 乱流渦のもつ運動量は, 液相密度 $\rho_{l}$ と全乱流エネルギー $k_{t}$ 及び気泡体積 $d_{b}{ }^{3}$ により, $\rho_{l} k_{t}^{1 / 2} d_{b}{ }^{3}$ で与えられる. また，Brown 運動における粒子数密度の勾配は，気泡数密度の勾配により与えられる．ここでは 図 2 (d) に示寸ように, 計算セル内の統計平均化された気相体積であるボイド率 $\alpha$ と気泡体積 $d_{b}{ }^{3}$ を用いて, 気 泡数密度が表現できるとする. これより, 気泡数密度の勾配が $\nabla\left(\alpha / d_{b}^{3}\right)$ と表現される. 従って, Brown 運動に基 づく乱流拡散力は乱流渦のもつ運動量と気泡数密度の勾配に比例し, 次式で表現される.

$$
\boldsymbol{M}_{T D} \propto \rho_{l} k_{t}^{1 / 2} d_{b}^{3} \nabla\left(\alpha / d_{b}^{3}\right)
$$

Brown運動では，粒子径に対し分子の大きさは無視できると考え，上述の様に分子の運動量は全て粒子に与え られると考えている. しかし，二相流には種々の大きさの乱流渦が含まれるため，気泡径に対して乱流渦の大き さを無視できない場合が想定され, このため, 乱流渦のもつ運動量の一部が気泡に与えられると考えられる. 乱 流拡散力は, 運動量保存式中に単位体積あたりの力として与える必要がある. 上式右辺は, 単位長さあたりの運 動量であるため, 運動量が交換される間に気泡が移動する距離と，流体塊が気泡に衝突する時間を考える必要が ある. 流体塊の衝突による気泡の移動距離を乱流長 $l_{t}$ と同程度とし, 流体塊の衝突時間を乱流渦が変動する時間で ある乱流変動時間 $\tau_{t}\left(\equiv k_{t} / \varepsilon\right)$ と同程度である考え, この衝突時間だけ渦 - 気泡間の運動量交換が行われるとする. また，乱流拡散力では，気泡に流体塊が衝突している間に，流体塊を駆動する乱流渦が消滅することが想定され る.つまり, 乱流渦の生存時間に対する移動時間の影響も無視できない. そこで本研究では, 気泡径 $d_{b}$ と渦スケ 一ル $l_{t}$ (乱流長 : $\left.\equiv k_{t}^{3 / 2} / \varepsilon\right)$ の比 $l_{t} / d_{b}$ 及び, 以下に示寸, 気泡応答時間 $\tau_{b}\left(\equiv d_{b}^{2} /(24 v)\right)^{(5)}$ と乱流変動時間 $\tau_{t}$ の比の関 数を導入する $\left(C_{\tau}\right.$ : モデル定数 $)$.

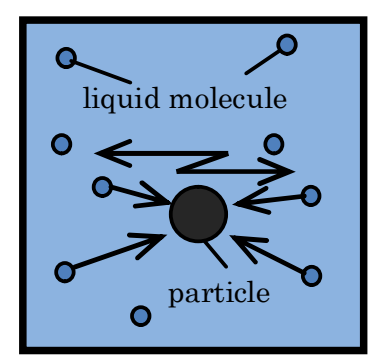

(a)

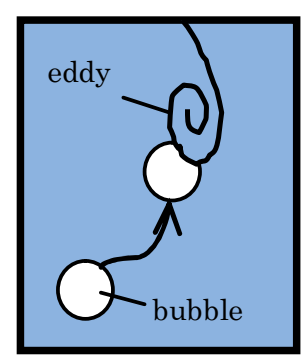

(b)

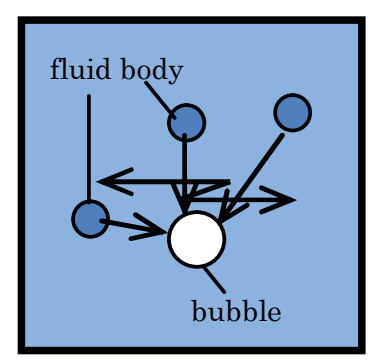

(c)

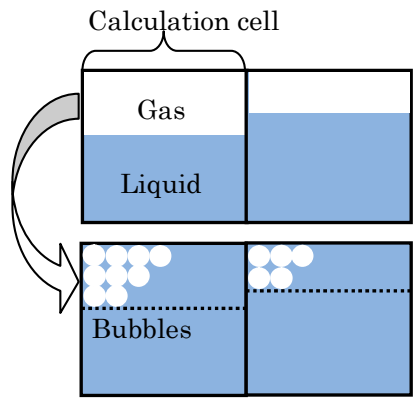

(d)

Fig. 2 Schematic diagram of Brownian motion and turbulent dispersion 


$$
f_{\tau} \equiv 1-\exp \left[-C_{\tau}\left(\tau_{b} / \tau_{t}\right)\right]
$$

以上より，乱流拡散力モデルを以下のようにモデル化する.

$$
\boldsymbol{M}_{T D}=C_{t d} f_{\tau} \frac{\rho_{l} k_{t}^{1 / 2}}{\tau_{t}} d_{b}^{3}\left(\frac{l_{t}}{d_{b}}\right) l_{t} \nabla\left(\frac{\alpha}{d_{b}^{3}}\right)=C_{t d} \rho_{l} d_{b}^{2}\left(\frac{k_{t}^{5 / 2}}{\varepsilon^{2}}\right)\left[1-\exp \left(-C_{\tau} \frac{\tau_{b}}{\tau_{t}}\right)\right] \nabla\left(\frac{\alpha}{d_{b}^{3}}\right)
$$

ここで, $C_{t d}$ はモデル定数, $\varepsilon$ は乱流散逸率であり，全乱流エネルギー $k_{t}$ はせん断誘起乱流エネルギー $k_{s i}$ と気泡誘 起乱流エネルギー $k_{b i}$ を用いて, 次式で与えられる(6).

$$
k_{t}=k_{s i}+k_{b i}
$$

\section{4. 適用性の検討}

\section{$4 \cdot 1$ 解析条件}

提案したモデルの適用性を評価するため, 管径 $200 \mathrm{~mm}^{(7)}$ 及び $38 \mathrm{~mm}^{(8)}$ の実験体系を模擬した解析を実施した. 表 1 に解析条件及びモデル定数を示す，気泡径は実験で測定された平均值を用い，それぞれの体系で気相見かけ 速度の異なる 2 条件を解析した。壁境界には壁関数を用いた。なお，式（7）中の $k_{b i}$ は考慮していない.

\section{$4 \cdot 2$ 解析結果及び考察}

図 3 (a)，（b）に両条件における半径方向ボイド率分布を示す．図３（a）より，大口径管において，管中心付 近の挙動に対する気相見かけ速度の影響や, 壁面近傍でのボイド率の増加などの定性的な挙動が再現されている. しかし，低い見かけ速度では壁面近傍で，高い見かけ速度では管中心近傍でボイド率を過小評価しており，モデ ル定数の最適化が必要であることが分かる. 図 3（b）より，中口径管においても，管中心及び壁面付近では定性 的な挙動が再現されている. しかし, 気相見かけ速度に関わらず, $r / R=0.7$ 近傍から管中心に向からボイド率の減 少傾向を解析結果が過大評価していることが分かる．この一因としては，流路の代表長さに対寸る気泡径の比が 相対的に大きい中口径管では，せん断誘起乱流に対する気泡誘起乱流の影響が相対的に大きく，この影響を無視 したことにより，気泡の拡散が抑制されたと思われる，そこで，液相の速度変動を実験結果と比較し，図 3 (c) に示す. 実験值は主流方向の変動であり, 解析結果は等方性乱流を仮定し, 乱流エネルギーより求めた. 図 3 (c)

\begin{tabular}{|c|c|c|c|c|}
\hline & \multicolumn{2}{|c|}{$200 \mathrm{~mm}$ case } & \multicolumn{2}{|c|}{$38 \mathrm{~mm}$ case } \\
\hline Pipe diameter $D[\mathrm{~mm}]$ & \multicolumn{2}{|c|}{200} & \multicolumn{2}{|c|}{38} \\
\hline Pipe length $L[\mathrm{~m}]$ & \multicolumn{2}{|c|}{12} & \multicolumn{2}{|c|}{4.5} \\
\hline Bubble diameter $d_{b}[\mathrm{~mm}]$ & \multicolumn{2}{|c|}{3.5} & \multicolumn{2}{|c|}{3.0} \\
\hline$J_{l}[\mathrm{~m} / \mathrm{s}]$ & \multicolumn{2}{|c|}{1.06} & \multicolumn{2}{|c|}{1.08} \\
\hline$J_{g}[\mathrm{~m} / \mathrm{s}]$ & 0.033 & 0.11 & 0.11 & 0.23 \\
\hline$\alpha$ & 0.02 & 0.06 & 0.059 & 0.122 \\
\hline$C_{t d}$ & \multicolumn{4}{|c|}{-5.0} \\
\hline$C_{\tau}$ & \multicolumn{4}{|c|}{0.3} \\
\hline Turbulent model & \multicolumn{4}{|c|}{ Two-phase $k$ - $\varepsilon$ model $^{(6)}$} \\
\hline Wall boundary & \multicolumn{4}{|c|}{ Wall function } \\
\hline
\end{tabular}
より, 液相変動速度が全領域で過小評価されており，r/R<0.7 においてその傾向は顕著である. これは，上述の様

Table 1 2-dimentional analyses conditions (Cylindrical coordinate) 


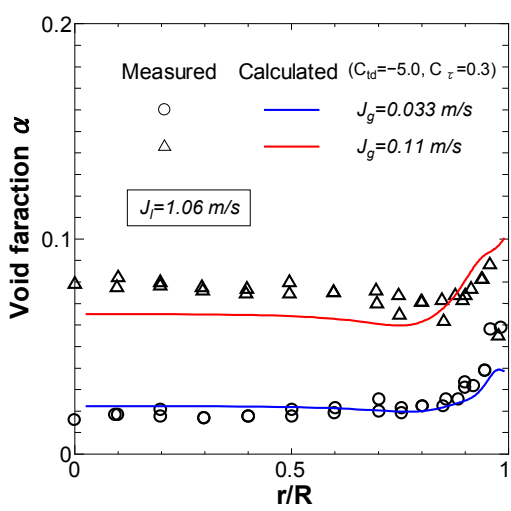

(a) Void fraction in $200 \mathrm{~mm}$ case

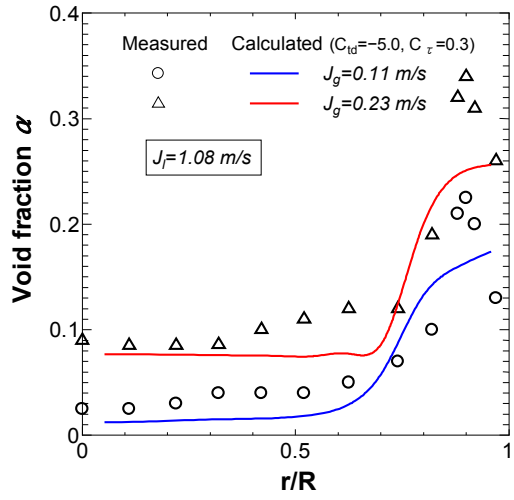

(b) Void fraction in $38 \mathrm{~mm}$ case

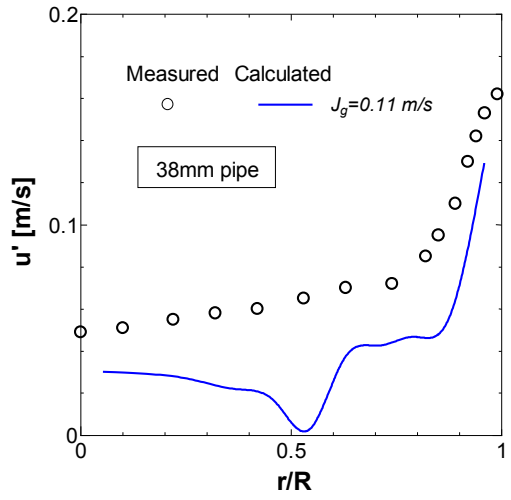

(c) Liquid velocity fluctuation ${ }^{(9)}$

Fig.3 Prediction results using suggested model

に，気泡誘起乱流の効果を無視したことが原因と考えられ，この影響により，ボイド率の勾配が大きい $r / R=0.7$ 近傍において, 定性的な傾向が再現されないものと思われる. 従って, 中口径以下の径を有する流路に対しては, 気泡誘起乱流の影響を考慮する必要があることが分かる.

\section{5. 結 言}

改良二流体モデルに適合した構成式の開発にあたり, 従来の構成式を検討した結果, 乱流拡散力のモデル化が 必要であると判断した. Brown 運動との類似性をもとに, 相違点についても考慮し, 新たな乱流拡散力モデルを 開発した. 開発したモデルの妥当性を評価するため, 管径 $200 \mathrm{~mm}$ の大口径管及び管径 $38 \mathrm{~mm}$ の中口径管を用い た水一空気系実験を模擬した解析を実施した。これらの結果から，大口径管では本モデルが定性的な現象を表現 寸ることを確認したが，中口径管に対しては，定性的な予測精度が不十分であり，この一因として，気泡誘起乱 流の効果を無視したことが影響していることを確認した。流路寸法が小さい体系に対しては，さらに予測精度が 低下寸る可能性があることから, 気泡誘起乱流の効果を本モデルに導入する必要があることが分かった。

\section{文献}

(1) Yoshida, H., Ohnuki, A., Misawa, T., Takase, K. and Akimoto, H., "Development of Analytical Procedures of Two-Phase Flow in Tight-Lattice Fuel Bundles for Innovative Water Reactor for Flexible Fuel Cycle", Int. J. American Nuclear Society, Vol.164, No.1 (2008), pp. 45-54.

(2) Yoshida, H., Hosoi, H., Suzuki, T. and Takase, K., "Development of Advanced Two-Fluid Model for Boiling Two-Phase Flow in Rod Bundles", Proc. of ICONE18, Xi'an (2010), ICONE18-30219.

(3) Hosoi, H. and Yoshida, H., "Model Development of Turbulent Dispersion Force for Advanced Two-Fluid Model in Consideration of Bubble-Liquid Interactions", Proc. of ICONE18, Xi'an (2010), ICONE18-29517.

(4) 米沢富美子, “ブラウン運動”, (1986), 共立出版.

(5) 牛島達夫, “乱流中での微小な粒子・液滴・気泡の混合・拡散について”, ながれ, Vol.23 (2004), pp.191-201.

(6) Lopez de Bertodano, M., Lahey, R.T. and Jones, O.C., "Development of a $k-\varepsilon$ Model for Bubbly Two-Phase Flow", J. Fluid Eng., Vol.116 (1994), pp. 128-134.

(7) Ohnuki, A. and Akimoto, H., "Experimental study on transition of flow pattern and phase distribution in upward air-water two-phase flow along a large vertical pipe", Int. J. Multiphase Flow, Vol.26, No.3 (2000), pp. 367-386.

(8) Liu, T. and Bankoff, S.G., "Structure of air-water bubbly flow in a vertical pipe-II. Void fraction, bubble velocity and bubble size distribution", Int. J. Heat Mass Transfer, Vol.36, No.4 (1993), pp.1061-1072.

(9) Liu, T. and Bankoff, S.G., "Structure of air-water bubbly flow in a vertical pipe-I. Liquid mean velocity and turbulence measurements", Int. J. Heat Mass Transfer, Vol.36, No.4 (1993), pp.1049-1060. 